\title{
Effect of dietary mannan oligosaccharide with or without oregano essential oil and hop extract supplementation on the performance and slaughter characteristics of male broilers
}

\author{
M. Bozkurt", K. Küçükyılmaz, A.U. Çatlı and M. Çınar \\ Poultry Research Institute, 09600 Erbeyli-Aydın, Turkey
}

\begin{abstract}
The effects of some alternative feed additives for antibiotic growth promoters on performance and some slaughter characteristics were examined in broilers fed wheat-soya based basal starter and finisher diets. A total of 2160 one-day-old male broiler chicks were randomly allocated to six groups with six replicate pens per treatment. The treatments were the basal diet (Control), and the basal diet supplemented with an antibiotic growth promoter (AGP); a prebiotic, mannan oligosaccharide (Bio-Mos, MOS); an essential oil of oregano (Herb-Mos Oregano, HMO); a plant extract of hop (Herb-Mos Hops, HMH) or a mixture of Herb-Mos Oregano and Herb-Mos Hops (HMOH). There were significant effects of dietary treatments on body weight and feed conversion ratio in the $0-21 \mathrm{~d}$ period, and on body weight and feed consumption in the $0-42 \mathrm{~d}$ period. The addition of all experimental additives to the diet resulted in significantly higher body weights as compared to the control treatment at both 21 and 42 days of age. Feed intakes were significantly different between the treatments at $0-21 \mathrm{~d}$ and $22-42 \mathrm{~d}$ periods, but not during the $0-42 \mathrm{~d}$ period. However, during the $0-21 \mathrm{~d}$ period the broiler chickens that received diets supplemented with AGP, MOS, HMO, HMH and HMOH had significantly better feed conversion ratios than the control group, but this pattern was not sustained during the finisher period (22 - $42 \mathrm{~d}$ ). Mortality rate, hot carcass yield and relative weights of the small intestines, pancreas, abdominal fat and bursa of fabricius were not affected by experimental treatments. The HMH supplementation increased relative liver weight. These results showed that AGP, MOS and herbal feed additive (HMO, $\mathrm{HMH}, \mathrm{HMOH})$ supplementation to a diet provided significant advantages on broiler growth performance through a 42-d growth period. However, the combined supplementation of HMO and HMH did not exert either synergistic or additive benefits on the live performance of the broilers. These results also proved that MOS, HMO, HMH and HMOH improved broiler live performance as well as an AGP in both the starter and through the grower period. Furthermore, outstanding advantages were evidenced for the HMH treatment in particular. Therefore, the MOS, HMO, $\mathrm{HMH}$ and $\mathrm{HMOH}$ performance enhancer feed additives of natural origin may be considered as potential substitutes for AGP in broiler diets.
\end{abstract}

Keywords: Antibiotic, mannan oligosaccharide, oregano essential oil, hop extract, broiler performance, slaughter characteristics

${ }^{\#}$ Corresponding author. E-mail: mehmetbozkurt9@hotmail.com

\section{Introduction}

Medical and consumer pressure and interest resulted in the systematic removal of antibiotics from animal feed in the European Union, and it was banned completely at the beginning of 2006 (Nollet, 2005; Wakeman 2005; Cervantes, 2006). Consequently, the poultry industry has been looking for substances that could replace antibiotic growth promoters (AGP) in feed (Mellor, 2000; Bach Knudsen, 2001). Various types of feed additives have been evaluated under commercial conditions and in experimental trials with the objective of achieving improved growth and the best economic return (Gill, 1999; 2001; Langhout, 2000). Mannan oligosaccharide (MOS) derived from the cell walls of Saccharomyces cerevisia exerts an antimicrobial mode of action by selectively binding pathogenic bacteria including Salmonella spp. and Escherichia coli, and inhibiting adhesion to enterocytes. In addition, MOS serves as an immune modulator, thus stimulating immune responses. Consequently, improving the health status of the intestinal mucosa due to feeding diets containing MOS could lead to improved growth performance, feed efficiency and liveability of broiler chickens (Spring, 1999; Shane, 2001; 2005; Ferket, 2004). Therefore, MOS as a feed additive has 
replaced AGP and has also proved its efficacy in scientific experiments and large-scale field trials (Waldroup et al., 2003a; b; Hooge, 2003a; b; 2004; Kocher, 2005). Recent evidence suggests that botanical feed additives could play significant roles, especially in synergistic combinations with other feed additives.

The AGPs have been replaced by a wide variety of additives extracted from herbs, spices and other plants and include essential oils, extracts, powders and dried whole parts of those botanicals. Essential oils that gained importance recently as AGP alternative natural feed additives have been extracted from aromatic plants by steam distillation, pressing or solvent extraction. Besides their well-known antimicrobial activity (Deans \& Ritchie, 1987; Cowan, 1999; Hammer et al., 1999; Dorman \& Deans, 2000; Ultee et al., 2002); many essential oils also exhibit antioxidant (Basmacioğlu et al., 2004; Botsoglou et al., 2002; 2004), antifungal (Montes-Belmont \& Carvajal, 1998; Shin \& Lim, 2004), anticoccidial (Allen et al., 1997, Evans et al., 2001) and enzymatic (Platel \& Sravinason, 1996; Jamroz et al., 2005) activities. The beneficial effects of essential oils, particularly the essential oil of oregano, on the live performance of broilers have been shown in scientific experiments either alone (Bassett, 2000; Hertrampf, 2001; Denli et al., 2004; Halle et al., 2004; Çiftçi et al., 2005) or in combination with other essential oils (Alçiçek et al., 2003; 2004; Jamroz et al., 2003; 2005; Zhang et al., 2005). Furthermore, hop has been credited with numerous medicinal uses, including antibacterial activity (Stavri et al., 2004). However, limited research has been performed on plant extracts, including hops, essential oils and MOS. In a preliminary study it has been demonstrated that the inclusion of ground hops into broiler diets at the rate of $0.45 \mathrm{~kg}$ per ton significantly improved growth rate and feed utilization in the absence of growth promoting antibiotics (Cornellison et al., 2006). The positive effect of a plant extract mixture of sage, thyme and rosemary on the live performance of broilers has also been reported in an earlier study (Hernandez et al., 2004). However, combining strategies may sometimes prove more beneficial than individual supplementation of feed additives. In piglets (Lückstädt et al., 2005) and in broiler chickens (Zhang et al., 2005), for example, essential oil-organic acid blends proved to be promising alternatives to AGPs. Therefore, the present study aimed to examine the combination of two different herbal feed additives, Herb-Mos Oregano (HMO) and Herb-Mos Hops (HMH), as novel commercial products with different modes of action to provide for a broad spectrum of growth promoters, immune stimulators, and antioxidative and digestive enhancers.

The objective of this study was not only to demonstrate the effectiveness of individual supplementation of an essential oil and a plant extract, but also to reveal possible synergistic or additive effects in terms of performance and general health of broiler chickens. It is noteworthy that, while MOS or essential oils have been studied individually as feed additives, in this study they are tested for the first time in combinations, as alternatives to AGP. Furthermore, the combined effect of an essential oil and plant extract has not been tested previously. Therefore, the aim of this study was to evaluate the ability of MOS and two plant products to stimulate broiler performance when used as supplements in broiler diets.

\section{Materials and Methods}

Two thousand one hundred and sixty day-old male broiler chicks of a commercial strain (Ross-308) were divided randomly into six treatment groups of 360 birds each. Each treatment group was further subdivided into six replicates of sixty birds per replicate. From days 1 to 21 the birds were fed a starter diet in crumble form and from days 22 to 42 a grower diet in pellet form (Table 1). The experimental diets were as follows: 1. Basal diet, no additives (Control), 2. Basal diet + an antibiotic (AGP - avilamycin, $10 \mathrm{mg} / \mathrm{kg}$ diet); 3. Basal diet + mannan oligosaccharide (MOS - Bio-Mos ${ }^{\circledR}, 1 \mathrm{~g} / \mathrm{kg}$ diet); 4. Basal diet + essential oil of oregano (HMO - Herb-Mos Oregano ${ }^{\circledR}, 1 \mathrm{~g} / \mathrm{kg}$ diet); 5. Basal diet + plant extract of hops (HMH - Herb-Mos Hops $^{\circledR}, 1 \mathrm{~g} / \mathrm{kg}$ diet) and, 6. Basal diet + mixture of Herb-Mos Oregano and Herb-Mos Hops (HMOH, $1 \mathrm{~g} / \mathrm{kg}$ diet). The Herb-Mos products consist of part Bio-Mos ${ }^{\circledR}$ into which either oregano essential oil or hop extract has been added. The experimental feed additives MOS, HMO, HMH, HMOH were supplied by ALLTECH (Alltech Biotechnology Centre, Ireland). The ingredient and chemical composition of the diets are presented in Table 1. The diets were isoenergetic and isonitrogeneous, and contained Allzyme PT (Alltech) as xylanase. Dietary feed additives were added at the expense of sawdust. All the experimental diets were formulated to meet the minimum nutrient requirements of broilers (NRC, 1994). The experimental diets and drinking water were provided ad libitum. The experiment was conducted in an environmentally controlled floor pen house of commercial design. The birds were kept in 36 pens $(2.4 \times 1.6 \mathrm{~m})$ on wood shavings as litter material. Each pen was equipped with two hanging feeders and one drinker. Bird density was 16 chicks per square meter. The lighting cycle was maintained at $23 \mathrm{~h} / \mathrm{d}$. The ambient temperature in the experimental 
house was maintained at $32{ }^{\circ} \mathrm{C}$ during the first week and gradually decreased by $3{ }^{\circ} \mathrm{C}$ in the second and third weeks, and was fixed at $22{ }^{\circ} \mathrm{C}$ thereafter. Chicks were vaccinated via their drinking water against Infectious Bursal Disease, New Castle Disease (HB1) and La sota at days 14, 21 and 28, respectively. During the $42 \mathrm{~d}$ experimental period, the growth of broilers was evaluated by recording body weight gain, feed intake, feed conversion ratio and mortality. Birds were weighed individually at 1,21 and $42 \mathrm{~d}$ of age. Feed intakes per pen were recorded at 21 and $42 \mathrm{~d}$ of age. The feed conversion ratio (FCR) was calculated as feed consumed per unit of body weight gain and was adjusted for weight of chicks at first day and bird mortality. FCR was determined at the end of the 21 days, and the 42-day experimental periods. Mortality was recorded daily and was used to adjust the total number of birds to determine the total feed intake per bird. At the end of the experiment (at d 42), 18 birds whose body weights were close to the group average were selected from each of the replicate groups of each treatment. These birds were slaughtered by severing the bronchial vein to determine some measurements of carcass yield, selected internal organs, abdominal fat pad and bursa of fabricius. The weights of selected internal organs (liver, pancreas and small intestines), abdominal pad weight and bursa of fabricius were measured individually. The weights of these internal organs were expressed as percentages of live body weight. The hot carcass yields were calculated as percentages of the preslaughter live body weight of broiler chickens. Standard techniques of the proximate analysis were used to determine the nutrient concentrations in the diets (Naumann \& Bassler, 1993). The experimental diets were also analysed for starch, sugar, total calcium and phosphorus according to analytical methods described by Naumann \& Bassler (1993). The metabolisable energy content of the diets was calculated based on chemical composition (Anonymous, 1991). The data obtained from this study were analyzed statistically using the General Linear Models procedure of SAS (1991). Significant differences between treatment means were separated using Duncan's multiple range test with a 5\% probability.

Table 1 The ingredients and chemical composition of the basal starter and grower diets (as fed)

\begin{tabular}{|c|c|c|c|c|c|}
\hline \multirow{2}{*}{ Ingredients $(\mathrm{g} / \mathrm{kg})$} & \multirow{2}{*}{ Starter diet } & \multirow{2}{*}{ Grower diet } & \multicolumn{3}{|c|}{ Chemical composition of basal diet (g/kg) } \\
\hline & & & & Starter diet & Grower diet \\
\hline Wheat & 525.1 & 573.1 & Dry matter & 893.9 & 896.0 \\
\hline Soyabean meal (48\%) & 118.0 & 102.4 & Crude protein & 232.0 & 214.0 \\
\hline Full-fat soyabean & 300.0 & 250.0 & Crude fat & 79.1 & 94.1 \\
\hline Soya oil & 14.3 & 35.2 & Crude fibre & 40.7 & 39.8 \\
\hline Dicalcium phosphate & 17.0 & 16.3 & Crude ash & 69.3 & 66.1 \\
\hline Ground limestone & 10.2 & 9.45 & Starch & 332.2 & 338.2 \\
\hline Salt & 2.50 & 2.50 & Sugar & 36.4 & 37.5 \\
\hline L-Lysine HCL & 1.66 & 1.05 & Calcium & 9,47 & 8,78 \\
\hline DL-methionine & 3.74 & 2.50 & Phosphorus (total) & 6,76 & 6.44 \\
\hline Vitamin premix $^{1}$ & 2.50 & 2.50 & \multicolumn{3}{|c|}{ Calculated composition $(\mathrm{g} / \mathrm{kg})$} \\
\hline Mineral premix ${ }^{2}$ & 1.00 & 1.00 & Available phosphorus & 4.7 & 4.4 \\
\hline Anticoccidial $^{3}$ & 1.00 & 1.00 & Lysine & 14.0 & 12.0 \\
\hline Antioxidant & 1.00 & 1.00 & Methionine & 7.0 & 5.5 \\
\hline Allzyme $\mathrm{PT}^{4}$ & 1.00 & 1.00 & Methionine + cysteine & 11.0 & 9.2 \\
\hline Sawdust & 1.00 & 1.00 & Linoleic acid & 38.7 & 45.1 \\
\hline Total & 1000 & 1000 & $\begin{array}{l}\text { Metabolisable energy } \\
(\mathrm{MJ} / \mathrm{kg})\end{array}$ & 13.16 & 13.49 \\
\hline
\end{tabular}

${ }^{1}$ Supplied per kg of diet: $12000 \mathrm{IU}$ vitamin $\mathrm{A} ; 1500 \mathrm{IU}$ vitamin $\mathrm{D}_{3} ; 30 \mathrm{mg}$ vitamin $\mathrm{E} ; 5 \mathrm{mg}$ vitamin $\mathrm{K}_{3} ; 3 \mathrm{mg}$ vitamin $\mathrm{B}_{1} ; 6 \mathrm{mg}$ vitamin $\mathrm{B}_{2} ; 5 \mathrm{mg}$ vitamin $\mathrm{B}_{6} ; 0.03 \mathrm{mg}$ vitamin $\mathrm{B}_{12} ; 40 \mathrm{mg}$ nicotine amid; $10 \mathrm{mg}$ calcium-D-pantothenate; $0.75 \mathrm{mg}$ folic acid; $0.075 \mathrm{mg} \mathrm{D}$-biotin; $375 \mathrm{mg}$ choline chloride.

${ }^{2}$ Supplied per kg of diet: $80 \mathrm{mg} \mathrm{Mn} ; 40 \mathrm{mg} \mathrm{Fe} ; 60 \mathrm{mg} \mathrm{Zn;} 5 \mathrm{mg} \mathrm{Cu} ; 0.5 \mathrm{mg} \mathrm{I} ; 0.2 \mathrm{mg} \mathrm{Co} ; 0.15 \mathrm{mg}$ Se.

${ }^{3}$ Provided $70 \mathrm{mg}$ Narasin per $\mathrm{kg}$ of diet.

${ }^{4}$ Xylanase based enzyme preparation. 


\section{Results and Discussion}

The effects of the experimental feed additives on body weight, feed intake, feed conversion ratio and mortality of broiler chickens are presented in Table 2. A significant growth promoting effect was observed from all feed additives. The AGP, MOS, HMO, HMH and HMOH supplementation to the diet increased body weight of broiler chickens both at 21 and 42 days of age compared to the control $(\mathrm{P}<0.01)$. Contrary to that pattern, no differences $(\mathrm{P}>0.05)$ were observed between the treatments during the finisher period $(22$ to $42 \mathrm{~d}$ ). Birds receiving the diet containing HMH exhibited the highest body weight both at three and six weeks of age. Dietary supplementation of AGP, MOS, HMO, HMH and HMOH enhanced the body weight of 21-d old chickens in relation to the control birds by 18.9, 16.7, 20.2, 23.5 and $21.8 \%$, respectively. A similar pattern was observed at 42 days with improvements of 5.2, 4.9, 4.4, 7.1 and $6.2 \%$, respectively. Despite the exceptional growth rate of $2.54 \mathrm{~kg}$ for the control treatment at 42 days of age, supplementation with the feed additives enhanced final body weight by at least $4 \%$. It is worth noting that the growth promoting effect of the HMH treatment for both 21-d and 42-d body weights was greater than those of the other experimental treatments, both alone and combined with HMO.

Table 2 Body weight, feed intake, feed conversion ratio and mortality of broilers given either AGP, MOS, $\mathrm{HMO}, \mathrm{HMH}$ or $\mathrm{HMOH}$ added diets

\begin{tabular}{|c|c|c|c|c|c|c|c|c|}
\hline \multirow{2}{*}{$\begin{array}{l}\text { Experimental period (d) } \\
\text { and parameter }\end{array}$} & \multicolumn{8}{|c|}{ Treatments } \\
\hline & Control & AGP & MOS & HMO & $\mathrm{HMH}$ & $\mathrm{HMOH}$ & s.e.m. & $P$ \\
\hline \multicolumn{9}{|l|}{ Body weight (g) } \\
\hline $21 \mathrm{~d}$ & $767^{\mathrm{e}}$ & $912^{\text {cd }}$ & $895^{\mathrm{d}}$ & $922^{\mathrm{bc}}$ & $947^{\mathrm{a}}$ & $934^{\mathrm{ab}}$ & 6.60 & 0.0001 \\
\hline $42 \mathrm{~d}$ & $2543^{\mathrm{c}}$ & $2674^{\mathrm{ab}}$ & $2667^{\mathrm{b}}$ & $2656^{\mathrm{b}}$ & $2723^{\mathrm{a}}$ & $2700^{\mathrm{ab}}$ & 18.28 & 0.0001 \\
\hline $22-42 d$ & 1776 & 1762 & 1772 & 1734 & 1776 & 1766 & 16.49 & 0.6943 \\
\hline \multicolumn{9}{|l|}{ Feed intake (g) } \\
\hline $0-21 \mathrm{~d}$ & 1271 & 1311 & 1311 & 1288 & 1309 & 1298 & 15.06 & 0.3847 \\
\hline $22-42 d$ & $3607^{\mathrm{b}}$ & $3769^{\mathrm{a}}$ & $3763^{\mathrm{a}}$ & $3734^{\mathrm{ab}}$ & $3831^{\mathrm{a}}$ & $3831^{\mathrm{a}}$ & 30.23 & 0.0496 \\
\hline $0-42 d$ & $4878^{\mathrm{b}}$ & $5080^{\mathrm{a}}$ & $5074^{\mathrm{a}}$ & $5022^{\mathrm{ab}}$ & $5140^{\mathrm{a}}$ & $5129^{a}$ & 63.26 & 0.0701 \\
\hline \multicolumn{9}{|c|}{ Feed conversion (g feed/g gain) } \\
\hline $0-21 \mathrm{~d}$ & $1.772^{\mathrm{a}}$ & $1.515^{\mathrm{bc}}$ & $1.545^{\mathrm{b}}$ & $1.471^{\mathrm{c}}$ & $1.457^{\mathrm{c}}$ & $1.462^{\mathrm{c}}$ & 0.02 & 0.0001 \\
\hline $22-42 d$ & $2.031^{\mathrm{b}}$ & $2.139^{\mathrm{a}}$ & $2.123^{\mathrm{a}}$ & $2.153^{\mathrm{a}}$ & $2.157^{\mathrm{a}}$ & $2.169^{\mathrm{a}}$ & 0.01 & 0.0010 \\
\hline $0-42 \mathrm{~d}$ & 1.954 & 1.934 & 1.935 & 1.924 & 1.919 & 1.933 & 0.01 & 0.2855 \\
\hline \multicolumn{9}{|l|}{ Mortality (\%) } \\
\hline $0-21 \mathrm{~d}$ & 0.28 & 2.25 & 3.38 & 2.54 & 2.25 & 1.69 & 0.72 & 0.1017 \\
\hline $0-42 \mathrm{~d}$ & 1.69 & 2.54 & 4.51 & 3.38 & 3.71 & 2.54 & 0.85 & 0.2247 \\
\hline
\end{tabular}

${ }^{\mathrm{a}-\mathrm{e}}$ Means with in row different superscript differ at $\mathrm{P}<0.05$; s.e.m. - standard error of mean.

AGP - antibiotic growth promoters; MOS - Bio-Mos; HMO - Herb-Mos Oregano; HMH - Herb-Mos Hops; $\mathrm{HMOH}$ - Herb-Mos Oregano plus Herb-Mos Hops.

The improved body weight gain of broilers receiving a diet with added HMO in this study agreed with results reported by Alçiçek et al. (2003; 2004). They reported that birds fed on the mixture of six different essential oils extracted from herbs growing in Turkey had significantly better body weights than those fed the basal diet and also diets containing an antibiotic, a probiotic and an organic acid. Likewise, Basset (2000) found that the supplementation of oregano essential oil through the drinking water $(150 \mathrm{~mL} / 1000 \mathrm{~L})$ increased the body weight of broilers by $4 \%$. Furthermore, some authors reported a growth promoting mode of action of essential oils in quail (Denli et al., 2004) and broilers (Jamroz et al., 2003; Halle et al., 2004; Çiftçi et al., 2005). Contrary to this, some earlier investigations indicated that essential oils or oil combinations did not improve body weight gain. Botsoglou et al. (2002) and Papageorgiou et al. (2003) found that dietary supplementation of essential oils derived from oregano at levels of 50 or $100 \mathrm{mg} / \mathrm{kg}$ to 
chickens and to turkeys $(200 \mathrm{mg} / \mathrm{kg})$ did not exhibit a growth promoter effect. Similar results were obtained by Basmacioğlu et al. (2004) who included oregano oils at two levels, $150 \mathrm{mg} / \mathrm{kg}$ diet and $300 \mathrm{mg} / \mathrm{kg}$ diet. Zhang et al. (2005) also reported that the supplementation of a mixture of essential oils from oregano, cinnamon, thyme and capsicum had no positive effect on the 42-d growth performance broiler. However, during the past decade the growth promoting effect of dietary MOS supplementation on broiler chickens has been demonstrated in numerous works which were conducted under different management conditions comprising different breeds, diet compositions, experimental periods, vaccination programmes and inclusion levels (Kumprecht et al., 1997; Sims \& Sefton, 1999; Shafey et al., 2001; Hooge et al., 2003b; Bozkurt et al., 2005a; b).

There are a few reports on the performance of broilers receiving the hop extract as a performance enhancer feed additive. In one of the few, it was demonstrated that the addition of $50 \mathrm{~g} /$ ton of antibiotic (penicillin) and ground hops at $0.45 \mathrm{~kg}$ per ton significantly increased the $14 \mathrm{~d}, 35 \mathrm{~d}$ and $42 \mathrm{~d}$ body weights of male broilers (Cornelison et al., 2006). On the other hand, there are some recent reports on the dietary effect of some other plant extracts. No significant differences on body weight gain of broilers were observed when thyme powder (Sarica et al., 2005) and a blend of extracts of sage, thyme and rosemary (Hernandez et al., 2004) were added to a diet.

The AGP improved the body weight and feed efficiency of broilers in comparison with the control. All herbal additive treatments and MOS fed to broilers gave a live performance similar to that of the AGP (avilamycin) under the conditions of our experiment. The result of this study also confirmed that the combined package of MOS and essential oil of oregano (HMO) or hop extract (HMH) can perform as an AGP in both the starter period and for the entire growth period of broiler chickens. An enhancing effect of antimicrobial feed additive (AGP) in combination with MOS on broiler 49-d growth performance was also proven by Hooge et al. (2003b). These authors reported that MOS alone improved live performance of broilers equivalent to antibiotics and demonstrated an additive effect when combined with antibiotics.

No differences in feed intake were observed between diets from 0 to $21 \mathrm{~d}$ of age $(\mathrm{P}>0.05)$. However, at $42 \mathrm{~d}$ of age the voluntary feed intakes of birds fed AGP, MOS, HMH and HMOH added diets were significantly higher than that of the control birds. This suggests that during the finisher period from 22 to 42 $\mathrm{d}$ of age all the experimental feed additives stimulated feed consumption significantly compared to the control treatment (Table 2). However, the vast majority of studies on dietary essential oil supplementation did not find any stimulating or depressive effect of oils on voluntary feed intake of broiler chickens. Noteworthy, variations related to the source and active components of essential oils, breed and age of the birds, management conditions, and ingredient and nutrient composition of the experimental diets did not affect the feed intake of birds in any of the studies (Hernandez et al., 2004; Basmacioğlu et al., 2004; Botsoglou et al., 2004; Zhang et al., 2005). The observed trend of herbal feed additives on feed consumption of broilers in our study agrees with those earlier reports only for the starter period, but differs from the grower and whole experimental periods due to the appetite stimulating effect. A similar stimulating effect on cumulative feed intake of an essential oil combination with significant performance improvements was reported by Alçiçek et al. (2004). Noteworthy, contrary to the results of these studies, two workers recently indicated that the oregano essential oil added to diets depressed cumulative feed intake of broilers at the same level, $147 \mathrm{~g}$ for Halle et al. (2004) and $150 \mathrm{~g}$ for Çabuk et al. (2006), despite significantly improved weight gains and feed efficiencies. On the other hand, hop extract (HMH) led to an over-consumption of the feed under our experimental conditions; conversely, the ground hops did not stimulate feed consumption of broilers as was formerly determined by Cornelison et al. (2006).

All feed additives improved the feed conversion ratio during the 0 to $21 \mathrm{~d}$ starter period $(\mathrm{P}<0.01)$ compared with the control, but not over the entire 0 to $42 \mathrm{~d}$ period. In fact, the control birds exhibited a better $(\mathrm{P}<0.05)$ FCR than the additive treatments during this period. Obviously, excessive feed consumption during the finisher period led to such a pattern even though all experimental treatments achieved similar body weight gains. The FCR of birds fed the HMO, $\mathrm{HMH}$ and $\mathrm{HMOH}$ added diets was significantly better than those of AGP and MOS added diets for the first $21 \mathrm{~d}$ of the experiment. Evidently, during the starter period the birds fed the diets containing the additives converted feed to body weight gain more efficiently $(\mathrm{P}<0.01)$ than the controls, but this was not sustained until the end of the experiment. Herbal additives fed to broilers led to better growth performance and feed efficiency than that of the control treatment, results that agree with those of Alçiçek et al. (2003; 2004) and Çabuk et al. (2006) who observed significant improvements on FCR in 42-d-old broilers fed a diet supplemented with the same herbal essential oil 
mixture $\left(\right.$ Herbromix $\left.^{\circledR}\right)$ containing oil of oregano, laurel leaf oil, sage leaf oil, myrtle leaf oil, fennel seed oil and citrus peel oil.

A number of reports has also provided evidence of the enhancement of FCRs through the dietary addition of carvacrol (Lee et al., 2003) and a mixture of essential oils including oregano, cinnamon, thyme and capsicum (Zhang et al., 2005). Significant improvements in FCR of broilers at $35 \mathrm{~d}$ of age were reported by Halle et al. (2004) who added oregano oil ranging from $0.1 \mathrm{~g} / \mathrm{kg}$ to $1.0 \mathrm{~g} / \mathrm{kg}$ to a diet. In agreement with the results of the present study, Cornelison et al. (2006) indicated that the addition of ground hops at $0.45 \mathrm{~kg}$ per ton feed also resulted in significant improvements in FCR and feed efficiency at all ages when compared to the negative control. Contrary to these findings, it was reported that dietary supplementation of essential oils (Basmacioğlu et al., 2004; Botsoglou et al., 2004; Hernandez et al., 2004; Lee et al., 2004a; b), thyme powder (Sarica et al., 2005), Chinese herb medicine formulation (Guo et al., 2004) and plant extracts (Hernandez et al., 2004) had no beneficial effects on FCR of broiler chickens even if the gender and age of bird, diet composition and nutrient density, active components and constituents of herbs were differentiated for the experiments. The lack of response of experimental feed additives on feed efficiency at a significant level at $42 \mathrm{~d}$ of age was attributed to the dietary use of a commercial enzyme preparation (Allyzme PTAlltech $^{\circledR}$ ) with a xylanase activity for wheat-based poultry diets. Therefore, the wheat-based dietary suppression on growth performance of broiler chickens might have been partially overcome by the inclusion of exogenous enzyme preparation to the diet. Antimicrobial and enzymatic activities of both might have reached peak levels in synergism, particularly in the starter period, when the endogenous enzyme activity of young birds was not effective enough. Thus, in the starter period the synergistic mode of action of enzymes with AGP, MOS, oregano essential oil and hop extract might have led to superior feed efficiencies compared to that of the control treatment. From another point of view, it could be suggested that dietary inclusion of an exogenous enzyme preparation in combination with herbal products at the recommended doses did not induce any adverse effect on the overall performance of broiler chickens.

Similar to the findings of this study, a beneficial effect on the feed conversion ratio has been reported frequently when broiler chickens were fed diets supplemented with MOS (Kumprecht et al., 1997; Sims \& Sefton, 1999; Shafey et al., 2001; Ceylan et al., 2003; Hooge et al., 2003b; Hooge, 2004; Bozkurt et al., 2005b). On the other hand, the results obtained in our study are in contrast to those of Engberg et al. (2000), Van Compenhout et al. (2001) and Sarica et al. (2005) who found no significant effect on voluntary feed intake and FCR when AGP was added into a wheat-based broiler diet. In fact, dietary inclusion of MOS and AGP resulted in intermediate feed conversion ratios between the control and herbal additives during the starter period in this study.

At 21 and 42 days of age, the mortality of birds was not affected by dietary treatments. In fact, beneficial effects of feed grade antibiotics and MOS on the overall health status of the broilers have been reported previously (Visek, 1978; Henry et al., 1986; Spring, 1999; Engberg et al., 2000; Shane, 2001; Ferket, 2004; Hooge, 2004). Several recent studies also noted beneficial effects of essential oils in preventing problems with coccidiosis (Allen et al., 1997; Evans et al., 2001), necrotic enteritis (Mitsch et al., 2004) and intestinal colonisation of E. coli and Salmonella typhimurium (Helander et al., 1998). However, recently published studies have indicated that the supplementation of essential oils to the diet did not improve the liveability of birds when compared to unsupplemented control treatment. The lack of response of herbal feed additives including essential oils on the broiler liveability in those studies were attributed to clean, hygienic and unstressed housing conditions (Lee et al., 2003; Basmacioğlu et al., 2004; Guo et al., 2004; Sarica et al., 2005). Contrary to those conclusions, AGP, MOS and herbal feed additive treatments could not provide a decrease in mortality in male birds even though they were reared under stocking density stress (43 $\mathrm{kg}$ live weight per $\mathrm{m}^{2}$ floor space).

The effects of the dietary additives on carcass yield and the relative weights of the small intestines, liver, pancreas, abdominal fat pad and bursa of fabricius are presented in Table 3. These slaughter characteristics were not influenced statistically by any of the dietary treatments $(\mathrm{P}>0.05)$. However, it is of note that the relative liver weight of chickens receiving the $\mathrm{HMOH}$ diets was numerically higher than those of the other treatments. A similar observation was reported by Debersac et al. (2001) who indicated that a plant extract from rosemary enhanced hepatic metabolism, and hence increased relative liver weight in rats. In contrast to our results, Alçiçek et al. $(2003 ; 2004)$ observed an improvement on carcass yield of broilers when supplemented with an essential oil combination in a broiler diet. In agreement with the results of our 
Table 3 Mean carcass yield and relative weight of some internal organs, abdominal fat and bursa of fabricius of broilers fed with AGP, MOS, HMO, HMH and HMOH supplemented diets

\begin{tabular}{lcccccccc}
\hline Organ weight, \% & Control & AGP & MOS & HMO & HMH & HMOH & s.e.m. & P \\
\hline Slaughter weight (g) & 2630 & 2655 & 2647 & 2653 & 2631 & 2646 & 17.57 & 0.8673 \\
Carcass yield & 77.29 & 76.26 & 77.31 & 76.74 & 76.95 & 77.98 & 0.49 & 0.2406 \\
Small intestines & 3.13 & 3.39 & 2.98 & 3.10 & 3.04 & 3.17 & 0.12 & 0.3139 \\
Liver & 224 & 2.23 & 2.27 & 2.36 & 2.31 & 2.54 & 0.07 & 0.0640 \\
Pancreas & 0.28 & 0.28 & 0.29 & 0.29 & 0.31 & 0.30 & 0.01 & 0.4882 \\
Abdominal fat & 1.54 & 1.19 & 1.40 & 1.23 & 1.46 & 1.59 & 0.12 & 0.1615 \\
Bursa of fabricius & 0.20 & 0.17 & 0.19 & 0.17 & 0.16 & 0.18 & 0.01 & 0.6913 \\
\hline
\end{tabular}

AGP - antibiotic growth promoters; MOS - Bio-Mos; HMO - Herb-Mos Oregano; HMH - Herb-Mos Hops; HMOH - Herb-Mos Oregano plus Herb-Mos Hops.

study, Basmacioğlu et al. (2004) and Sarica et al. (2005) found no beneficial effect of dietary supplementation of oregano essential oil and thyme powder, respectively, on the carcass yield of broiler chickens. Besides, a thinning effect on the intestinal wall of birds was induced by the antimicrobial activity of antibiotics (Henry et al., 1986), an experimental blend of MOS and organic acids (Bozkurt et al., 2005b) and essential oils (Alçiçek et al., 2004; Jamroz et al., 2005). However, this was not measured in the present study.

\section{Conclusion}

A dietary addition of feed additives as performance enhancers significantly improved broiler growth performance in comparison with the control, and this was associated with an increase in voluntary feed intake. Dietary supplementation of the essential oil of oregano (HMO) and hop extract (HMH) provided a significant improvement on body weight gain of broiler chickens when supplemented to the diet individually, but this improvement could not be enhanced through synergistic or additive mechanisms in terms of a combined inclusion (HMOH). Herbal feed additives when used in conjunction with MOS may act as gut environment stabilizers and provide synergism, thus maximizing the growth rate and feed efficiency without negatively affecting carcass yield and principal internal organ weights. As a consequence, data derived from this study suggest that the feed additive MOS, either alone or combined with the essential oil of oregano and hop extract, have the potential to replace growth promoting antibiotics in the production of broilers.

\section{Acknowledgments}

The authors gratefully acknowledge the financial support from ALLTECH (Alltech Biotechnology Centre, Ireland) with protocol number 04-E-895 in 2005 and valuable comments of Hüseyin Şener and Lode Nollet during the preparation of this paper.

\section{References}

Alçiçek, A., Bozkurt, M. \& Çabuk, M., 2003. The effects of an essential oil combination derived from selected herbs growing wild in Turkey on broiler performance. S. Afr. J. Anim. Sci. 33, 89-94.

Alçiçek, A., Bozkurt, M. \& Çabuk, M., 2004. The effects of a mixture of herbal essential oil, an organic acid or a probiotic on broiler performance. S. Afr. J. Anim. Sci. 34, 217-222.

Allen, P.C., Lydon, J. \& Danforth, H.D., 1997. Effects of components of Artemisia annua on coccidia infections in chickens. Poult. Sci., 76, 1156-1163.

Anonymous, 1991. Animal feeds - Determination of metabolizable energy (chemical method). Turkish Standards Institute (TSE), Publ. No. 9610, 1-3.

Bach Knudsen, K.E., 2001. Development of antibiotic resistance and options to replace antimicrobials in animal diets. Proc. Nutr. Soc. 60, 291-299. 
Basmacioğlu, H., Tokuşoğlu, Ö. \& Ergül, M., 2004. The effect of oregano and rosemary essential oils or alpha-tocopheryl acetate on performance and lipid oxidation of meat enriched with n-3 PUFA's in broilers. S. Afr. J. Anim. Sci. 34, 197-210.

Bassett, R., 2000. Oregano's positive impact on poultry production. Wrld Poult. 16 (9), 31-34.

Botsoglou, N.A., Florou-Paneri, P., Christaki, E., Fletouris, D.J. \& Spais, A.B., 2002. Effect of dietary oregano essential oil on performance of chickens and on iron-induced lipid oxidation of breast, thigh and abdominal fat tissues. Br. Poult. Sci. 43, 223-230.

Botsoglou, N.A, Christaki, E., Florou-Paneri, P., Giannenas, I., Papageorgiou, G. \& Spais, A.B., 2004. The Effect of a mixture of herbal essential oils or $\alpha$-tocopheryl acetate on performance parameters and oxidation of body lipid in broilers. S. Afr. J. Anim. Sci. 34, 52-61.

Bozkurt, M., Küçükyılmaz, K., Çatlı, A.U. \& Çınar, M., 2005a. Growth performance and carcass yield of broiler chickens given antibiotic, mannan oligosaccharide and dextran oligosaccharide supplemented diets. Nutritional Biotechnology in the Feed and Food Industries. Proc. $21^{\text {st }}$ Annual Symposium. May 22-25, 2005 Lexington, Kentucky, USA. (Suppl. 1). pp. 69.

Bozkurt, M., Küçükyılmaz, K., Çatl1, A.U., Çınar, M., 2005b.The effect of dietary supplementation of prebiotic, probiotic and organic acid, either alone or combined, on broiler performance and carcass characteristics. In: Proc. 15 ${ }^{\text {th }}$ European Symp. Poultry Nutrition. September 25-29, 2005, Balatonfüred, Hungary. pp. 288-290.

Çabuk, M., Bozkurt, M., Alçiçek, A., Akbaş, Y. \& Küçükyılmaz, K., 2006. Effect of herbal essential oil mixture on growth and internal organ weight of broilers from young and old breeder flocks. S. Afr. J. Anim. Sci. 36, 135-141.

Cervantes, H., 2006. Banning antibiotic growth promoters : Learning from the European experience. Poult. Int. 45 (6), 14-15.

Ceylan, N., Çiftçi, İ. \& İlhan, Z., 2003.The effects of some alternative feed additives for antibiotic growth promoters on the performance and gut miclora of broiler chicks. Turkish J. Vet. Anim. Sci. 27 (3), 727-733.

Çiftçi, M., Güler, T., Dalkıkıç, B. \& Ertaş, O.N., 2005. The effects of anise oil (Pimpinella anisum L.) on broiler performance. Int. J. Poult. Sci. (11), 851-855.

Cornelison, J.M., Yan, F., Watkins, S.E., Rigby L., Segal John, B. \& Waldroup, P.W., 2006. Evaluation of hops (Humulus lupulus) as an antimicrobial in broiler diets. Int. J. Poult. Sci. 5 (2), 134-136.

Cowan, M.M., 1999. Plant products as antimicrobial agents. Clin. Microbiol. Rev. 12, 564-582.

Deans, S.G. \& Ritchie, G., 1987. Antibacterial properties of plant essential oils. Int. J. Food Microb. 5, $165-180$.

Debersac, P., Vernevaut, M.F., Amiot, M.J., Suschetet, M. \& Siess, M.H., 2001.Effects of water-soluble extract of rosemary and its purified component rosmarinic acid on xenobiotic-metabolizing enzymes in rat liver. Food Chem. Toxicol. 29, 109-117.

Denli, M., Okan, F. \& Uluocak, A.M., 2004. Effect of dietary supplementation of herb essential oils on the growth performance, carcass and intestinal characteristics of quail (Coturnix coturnix japonica). S. Afr. J. Anim. Sci. 34, 174-179.

Dorman, H.J.D. \& Deans, S.G., 2000. Antimicrobial agent from plants: antimicrobial activity of plant volatile oils. J. Appl. Microbiol. 88, 308-316.

Engberg, R.M., Hedemann, M.S., Leser, T.D. \& Jensen, B.B., 2000. Effect of zinc bacitracin and salinomycin on intestinal microflora and performance of broilers. Poult. Sci. 79, 1311-1319.

Evans, J.W., Plunkett, M.S. \& Banfield, M.J., 2001. Effect of essential oil blend on coccidiosis in broiler chicks. Poult. Sci.80 (Supp. 1), 258 (Abstract).

Ferket, P.R., 2004. Alternatives to antibiotics in poultry production: Responses, practical experience and recommendations.nutritional biotechnology in the feed and food industries. In: Proc. Alltech's 20 th Annual Symposium. Ed. Lyons, T.P. \& Jacques, K.A., Nottingham University Press. pp. 57-67.

Gill, C., 1999. Herbs and plant extracts as growth enhancers. Feed Int. 20 (4), 20-23.

Gill, C., 2001. Safe and sustainable feed ingredients. Feed Int. 22 (3), 40-45.

Guo, F.C., Kwakkel, R.P., Soede, J., Williams, B.A. \& Verstegen, M.W.A., 2004. Effect of a Chinese herb formulation, as an alternative for antibiotics, on performance of broilers. Br. Poult. Sci. 45, 793-797. 
Halle, I., Thomann, R., Bauermann, U., Henning, M. \& Köhler, P., 2004. Effects of a graded supplementation of herbs and essential oils in broiler feed on growth and carcass traits. Landbauforshung Volkenrode 54, 219-229.

Hammer, K.A., Carson, C.F. \& Riley, T.V., 1999. Antimicrobial activity of essential oils and other plant extracts. J. Appl. Microbiol. 86, 985-990.

Helander, I.M., Alokomi, H.L., Latva-Kala, K., Mattila-Sandholm, T., Pol, I., Smid, E.J., Gorris, L.G.M. \& Von Wright, A., 1998. Characterization of the selected essential oil components on gram-negative bacteria. J. Agric. Food Chem. 46, 3590-3595.

Henry, P.R., Ammerman, C.B. \& Miles, R.D., 1986. Influence of virginiamycin and dietary manganese on perfomance, manganese utilization, and intestinal tract weight of broilers. Poult. Sci. 65, 321-324.

Hernandez, F., Madrid, J., Garcia, V., Orengo, J. \& Megias, M.D., 2004. Influence of two plant extracts on broiler performance, digestibility, and digestive organ size. Poult. Sci. 83, 169-174.

Hertrampf, J.W., 2001. Alternative antibacterial performance promoters. Poult. Int. 40, 50-52.

Hooge, D.M., 2003. Dietary mannan oligosaccharide improves broiler performance. Wrld Poult. 19 (4), 14-15.

Hooge, D.M., 2004. Meta-analysis of broiler chicken pen trials evaluating dietary mannan oligosaccharide, 1993-2003. Int. J. Poult. Sci. 3 (3), 163-174.

Hooge, D.M., Sims, M.D., Sefton, A.E., Connoly, A. \& Spring, P.S., 2003. Effect of dietary mannan oligosaccharide, with or without bacitracin or virginiamycin on live performance of broiler chickens at relatively high stocking density on new litter. J. Appl. Poult. Res. 12, 461-467.

Jamroz, D., Orda, J., Kamel, C., Wiliczkiewicz, A., Wertelecki, T. \& Skorupinska, J., 2003. The influence of phytogenetic extracts on performance, nutrient digestibility, carcass characteristics, and gut microbial status in broiler chickens. J. Anim. Feed Sci. 12, 583-596.

Jamroz, D., Wiliczkiewicz, A., Werteleck1, T., Orda, J. \& Sukorupinska, J., 2005. Use of active substances of plant origin in chicken diets based on maize and locally grown cereals. Br. Poult. Sci. 46, 485-493.

Kocher, A., 2005. AGP alternatives- part IV. Poultry production without AGPs- Challenges and solutions. Wrld Poult. 21 (9), 32-33.

Kumprecht, I., Zobac, P., Siske, V., Sefton, A.E. \& Spring, P., 1997. Effect of dietary mannan oligosaccharide level on performance and nutrient utilization of broilers. Poult. Sci. 76 (Suppl. 1), 132.

Langhout, P., 2000. New additives for broiler chickens. Wrld Poult. 16 (3), 22-27.

Lee, K-W., Everts, H., Kappert, H.J., Yeom, K,H. \& Beynen, A.C., 2003. Dietary carvacrol lowers body weight gain but improves feed conversion in female broiler chickens. Appl. Poult. Res. 12, 394-399.

Lee, K-W., Everts, H., Kappert, H.J., Van der Kuilen, J., Lemmens, A.G., Frehner, M. \& Beynen, A.C., 2004a. Growth performance, intestinal viscosity, fat digestibility and plasma cholesterol in broiler chickens fed a rye-containing diet without or with essential oil components. Int. J. Poult. Sci. 3 (9), 613-618.

Lee, K-W., Everts, H., Kappert, H.J. \& Beynen, A.C., 2004b. Growth performance of broiler chickens fed a carboxymethyl cellulose containing diet with supplemental carvacrol and/or cinnamaldehyde. Int. J. Poult. Sci. 3 (9), 619-622.

Lückstädt, C., 2005. Acid-phytobiotic blends. a sustainable alternative for feed safety, animal health and natural growth promotion in pig farming. Feed Mix 13 (4), 25-27.

Mellor, S., 2000. Nutraceuticals-alternatives to antibiotics. Wrld Poult. 16 (2), 30-33.

Mitsch, P., Zitter-Eglseer, K., Köhler, B., Gabler, C., Rosa, R. \& Zimpernik, I., 2004. The effect of two different blends of essential oil components on the proliferation of Clostridium perfringens in the intestines of broiler chickens. Poult. Sci. 83, 669-675.

Montes-Belmont, R. \& Carvajal, M., 1998. Control of Aspergillus flavus in maize with plant essential oils and their components. J. Food Protec. 61, 616-619.

NRC, 1994. Nutrient Requirements of Poultry. 9th rev. ed. National Research Council, National Academy Press, Washington, D.C., USA.

Naumann, C. \& Bassler, R., 1993. Chemical Analyses of Feedstuff. Method book III. (3 ed.). VDLUFAPress. Darmstadt, Germany.

Nollet, L., 2005. AGP alternatives-part I. EU close to a future without antibiotic growth promoters. Wrld Poult. 21 (6), 14-15. 
Papageorgiou, G., Botsoglou, N., Govaris, A., Giannenas, I., Iliadis, S. \& Botsoglou, E., 2003. Effects of dietary oregano oil and $\alpha$-tocopheryl acetate supplementation on iron-induced lipid oxidation of turkey breast, thigh, liver and hearth tissues. J. Anim. Physiol. Anim. Nutr. 87, 324-335.

Platel, K. \& Srinavasan, K., 1996. Influence of dietary species or their active principles on digestive enzymes of small intestinal mucosa in rats. Int. J. Food Sci. Nutr. 47, 55-59.

Sarica, S., Ciftci, A., Demir, E., Kilinc, K. \& Yıldırım, Y., 2005. Use of an antibiotic growth promoter and two herbal natural feed additives with and without exogenous enzymes in wheat based broiler diets. S. Afr. J. Anim. Sci. 35, 61-72.

SAS, 1991. SAS ${ }^{\circledR}$ User's Guide: Statistics. Version 6.03 edition .SAS Institute Inc., Cary, N.C., USA.

Shafey, T.M., Al-Mufarej, S., Shalaby, M.I. \& Jarlenabi, A.J., 2001. The effect of feeding mannanoligosaccharides (Bio-Mos) on the performance of meat chickens under two different vaccination programs. Asian-Aust. J. Anim. Sci. 14, 559-563.

Shane, M.S., 2001. Mannan oligosaccharides in poultry nutrition: mechanism and benefits. In: Proc. Alltech's $17^{\text {th }}$ Ann. Symp. Science Technology in the Feed Industry. Ed. Lyons, T.P. \& Jacques, K.A., Nottingham University Press. pp. 65-77.

Shane, S., 2005. Antibiotic alternatives in turkey production. Wrld Poult. 19 (4), 14-15.

Shin, S. \& Lim, S., 2004. Antifungal effects of herbal essential oils alone and in combination with ketaconazole against Trichophyton spp. J. Appl. Microbiol. 97, 1289-1296.

Sims, M.D. \& Sefton, A.E., 1999. Comparative effects of mannan oligosaccharide and an antibiotic growth promoter on performance of commercial broilers. Poster presented at the $50^{\text {th }}$ North Central Avian Disease Conference, Vancouver, British Columbia, Canada.

Spring, P., 1999. Modes of action of dietary mannan oligosaccharide as a growth enhancer. Zootech. Int. 22, 34-36.

Stavri, M., Schneider, R., O’Donnell, G., Lechner, D., Bucar, F. \& Gibbons, S., 2004. The antimycobacterial components of hops (Humulus lupulus) and their dereplication. Phytotheraphy Res. 18, 774-776.

Ultee, A., Kets, E.P.W. \& Smid, E.J., 2002. Mechanisms of action of carvacrol on the food borne pathogen Bacillus cereus. Appl. Environ. Microbiol. 65, 4606-4610.

Van Compenhaut, L., Van Hemel, J., Vandenkerckhove, J., Mollen, K. \& Sas, B., 2001. Performance of an alternative to antibiotics in broilers with high intestinal counts of Clostridium perfiringens. In: Proc. $13^{\text {th }}$ Eur. Symp. on Poult. Nutr., Blankenberge, Belgium. pp. 127-128.

Visek, W.J., 1978. The mode of growth promotion by antibiotics. J. Anim. Sci. 46, 1447-1469.

Wakeman, G.W., 2005. AGP alternatives- part II. Dietary strategies to influence bacterial microflora. Wrld Poult. 21 (7), 28-29.

Waldroup, P.W., Edgar, O., Oviedo-Rondon \& Fritts, C.A., 2003a. Comparison of Bio-Mos ${ }^{\circledR}$ and antibiotic feeding program in broiler diets containing copper sulphate. Int. J. Poult. Sci. 2 (1), 28-31.

Waldroup, P.W., Fritts, C.A. \& Fenglan Yan, 2003b. Utilization of Bio-Mos ${ }^{\circledR}$ mannan oligosaccharide and Bioplex ${ }^{\circledR}$ copper in broiler diets. Int. J. Poult. Sci. 2 (1), 44-52.

Zhang, K.Y., Yan, F., Keen, C.A. \& Waldroup, P.W., 2005. Evaluation of microencapsulated essential oils and organic acids in diets for broiler chickens. Int. J. Poult. Sci. 4 (9), 612-619. 